\title{
PERNIKAHAN LINTAS IMAN DALAM KONTEKS MASYARAKAT MAJEMUK
}

\section{Robert Patannang Borrong, Ph.D.}

\begin{abstract}
Abstrak
meninjau persoalan perkawinan campur beda agama yang diistilahkan perkawinan lintas iman, dalam konteks Negara majemuk, terutama dari sudut pandang etika/moral yang dikaitkan dengan sudut pandang hukum dan teologi. Dengan sengaja menggunakan istilah perkawinan lintas iman karena iman adalah sesuatu yang mencerminkan hubungan seseorang dengan Tuhan, apapun agamanya, sedangkan agama adalah institusi yang memfasilitasi iman. Orang yang mau menikah dengan orang yang berbeda agama tetapi suka mempertahankan agama masing-masing seharusnya dilandaskan pada keyakinan iman dan bukan sekedar agama.
\end{abstract}

\section{Kata-Kata Kunci :}

Perkawinan campur, iman, HAM, masyarakat majemuk,negara.

\section{Pengantar}

Perkawinan adalah hak setiap orang tanpa harus dibatasi oleh perbedaan-perbedaan yang bersifat primordial. Dalam Deklarasi Umum mengenai Hak Asasi Manusia (DUHAM) Artikel 16 dinyatakan bahwa laki-laki dan perempuan yang telah mencapai usia dewasa, berhak untuk menikah tanpa dibatasi oleh yang bekaitan dengan ras, kebangsaan dan agama. (Article 16 of the Universal Declaration of Human Rights, men and women who have attained the age of majority have the right to marry "without any limitation due to race, nationality or religion"). ${ }^{1}$ Jadi menurut DUHAM perkawinan dua orang yang berbeda keyakinan imannya atau yang

\footnotetext{
${ }^{1}$ https://en.wikipedia.org/wiki/Interfaith marriage, diakses 29 Mei 2017.
} 
populer dengan sebutan "berbeda agama", tidak seharusnya dihalangi atau dilarang. Perkawinan dua orang yang berbeda iman atau anutan agama tidak dianggap sebagai perkawinan terlarang.

DUHAM mengikat bangsa Indonesia secara hukum karena Indonesia telah meratifikasi salah satu dokumen implementasi dari DUHAM yaitu dokumen Kovenan Internasional tentang Ekonomi, Sosial dan Budaya (Kovenan EKOSOB) yang ditetapkan oleh Majelis Umum PBB tanggal 16 Desember 1966 dan diratifikasi oleh pemerintah Indonesia pada tanggal 26 Februari 2006. ${ }^{2}$ Pasal 10 nomor 1 menegaskan bahwa Negara Pihak Pada Kovenan ini mengakui bahwa "Perlindungan atas bantuan seluas mungkin harus diberikan kepada keluarga yang merupakan kelompok alamiah dan mendasar dari satuan masyarakat, terutama terhadap pembentukannya, dan sementara itu keluarga bertangguing jawab atas perawatan dan pendidikan anak-anak yang masih dalam tanggungan. Perkawinan harus didasarkan atas pertetujuan yang sukarela dari calon mempelai". ${ }^{3}$ Oleh karena Indonesia telah meratifikasi Kovenan EKOSOB maka Indonesia terikat untuk melaksanakannya secara konsekuen. Dalam konteks tulisan ini perlu diperhatikan secara khusus dasar perkawinan yaitu persetujuan yang sukarela dari calon mempelai; dan kewajiban negara memberikan perlindungan dan bantuan pembentukan keluarga (pernikahan/perkawinan).

Dalam Undang-undang Dasar 1945 (UUD45) hasil amandemen, pasal 28 B nomor 1 menyebutkan bahwa "setiap orang berhak membentuk keluarga dan memperoleh keturunan melalui perkawinan yang sah". ${ }^{4}$ Tidak ada penjelasan terhadap bunyi pasal ini. Sejak UUD 45 diamandemen dan mencantumkan secara eksplisit pasal mengenai perkawinan, tinjauan terhadap

\footnotetext{
${ }^{2}$ http://referensi.elsam.or.id/2014/09/kovenan-internasional-hak-ekonomi-sosial-dan-budaya/, diakses, 29 Mei 2017.

${ }^{3}$ https://www.kontras.org/baru/Kovenan\%20Ekosob.pdf, diakses 30 Mei 2017.

4 https://portal.mahkamahkonstitusi.go.id/eLaw/mg58ufsc89hrsg/UUD 1945 Perubahan.pdf, diakses, 30 Mei 2017.
} 
Undang-undang Nomor 1 tahun 1974 tentang Perkawinan, belum pernah dilakukan dan disesuaikan. Terlebih dalam alam demokrasi pasca era reformasi di Indonesia, kebebasan dalam memilih pasangan hidup, khususnya oleh orang-orang yang berbeda agama, masih menghadapi banyak kendali, misalnya dalam hal layanan dari pihak negara, khususnya pemerintah. Pelayanan terhadap orang-orang yang mau menikah tetapi berbeda agama dan mau mempertahankan agama masing-masing, menghadapi jalan buntuh dalam pelayanan negara.

Tulisan kecil ini meninjau persoalan perkawinan campur beda agama yang saya istilahkan perkawinan lintas iman, dalam konteks Negara majemuk, terutama dari sudut pandang etika/moral yang dikaitkan dengan sudut pandang hukum dan teologi. Dengan sengaja saya menggunakan istilah perkawinan lintas iman karena iman adalah sesuatu yang mencerminkan hubungan seseorang dengan Tuhan, apapun agamanya, sedangkan agama adalah institusi yang memfasilitasi iman. Orang yang mau menikah dengan orang yang berbeda agama tetapi suka mempertahankan agama masing-masing seharusnya dilandaskan pada keyakinan iman dan bukan sekedar agama. Sebaliknya, orang yang mau menikah dan mengubah agamanya bukanlah seorang beriman. Karena kebanyakan literatur menggunakan istilah kawin campur beda agama, terminologi ini tetap digunakan sesuai konteksnya.Tulisan ini terlebih dulu meninjau secara singkat persoalan hukum di Indonesia yang mengabaikan pelayanan bagi warga Negara yang menikah tetapi dengan keyakinan agama yang berbeda dan pihak-pihak yang menikah ingin mempertahankan keyakinan agamanya masing-masing. Kemudian tinjauan sepintas sikap agama-agama yang ada di Indonesia, khususnya Islam dan Kristen dan akhirnya tinjauan dari sudut pandang etika, secara khusus sudut pandang Etika Kristen.

\section{Sudut Pandang Hukum terhadap Perkawinan Lintas Iman.}


Dalam Pasal 2 nomor 1, Undang-undang Nomor 1 tahun 1974 tentang Perkawinan. disebutkan bahwa perkawinan adalah sah apabila dilakukan menurut hukum masing-masing agamanya dan kepercayaannya itu. Pertanyaan penting untuk dijawab, baik secara konsepsional maupun secara praktis dengan mengacu kepada pasal tersebut di atas ialah apakah yang dimaksud dengan hukum masing-masing agamanya dan kepercayaannya itu? Banyak orang menganggap bahwa pasal tersebut menunjuk kepada Hukum Agama yang mengatur perkawinan, yang dimiliki oleh semua agama (waktu itu diakui hanya 5 agama: Islam, Kristen, Katolik, Hundu dn Budha; sesudah tahun 2000, Kong Hu Chu diakui juga sebagai Agama berdasarkan Keputusan Presiden No. 6 tahun 2000, yang isinya Presiden Abdul Rachman Wahid mencabut Kepres No. 14 tahun1967 yang melarang Khong $\mathrm{Hu} \mathrm{Cu}$ di Indonesia). ${ }^{5}$ Itu juga bisa berarti perkawinan yang diselenggarakan secara Adat atau perkawinan yang diselenggarakan oleh Aliran-aliran Kepercayaan tidak lagi dianggap sah.

Ketentuan sahnya perkawinan menurut Pasal 2 ayat 1 tadi dengan sendirinya mencegah kemungkinan pelayanan agama terhadap perkawinan lintas iman atau perkawinan campur orang berbeda agama, sebab tidak mungkin hukum agama yang mengatur perkawinan dua orang seagama dapat diterapkan kepada perkawinan dua orang yang berbeda agama. Lagi pula, dalam UU No. 1 tahun1974 itu tidak diatur secara eksplisit layanan terhadap perkawinan dua orang berbeda agama. Akibatnya, pelayanan terhadap warga Negara Indonesia yang menikah tetapi berbeda anutan agamanya dan masing-masing suka mempertahankan agama masing-masing, tidak bisa lagi mendapat layanan pemerintah karena persyaratan hukum masing-masing agama tidak memberi peluang untuk itu.

\footnotetext{
${ }^{5}$ http://wisnu.blog.uns.ac.id/2011/03/10/pengakuan-agama-khonghucu-di-indonesia/, diakses 15 Juni 2017
} 
Pasal 8, f Undang-undang Nomor 1 tahun 1974 dengan tegas melarang "perkawinan antara dua orang yang oleh agamanya atau peraturan lain yang berlaku di larang kawin”. Pasal ini menjadi alasan Pejabat Pencatat Perkawinan untuk mencegah perkawian orang yang berbeda agama sesuai dengan Pasal 16 (1), bahwa Pejabat yang ditunjuk berkewajiban mencegah berlangsungnya perkawinan apabila ketentuan dalam pasal 8 tidak terpenuhi. Bahkan menurut Pasal 20, Pegawai pencatat perkawinan tidak diperbolehkan melangsungkan atau membantu melangsungkan perkawianan bila mengetahui adanya pelanggaran dari ketentuan pasal 8 . Semua pasal ini dan khususnya pasal 2 (1) menutup kemungkinan terjadinya perkawinan campur beda agama atau perkawinan lintas iman bagi warga Negara Indonesia.

Perkawinan campur beda agama atau perkawinan lintas iman memang tidak diatur dalam Undang-undang Nomor 1 tahun 1974 tentang Perkawinan sebab perkawinan campur yang diatur hanyalah perkawinan campuran antar warganegara. Dalam Pasal 57 ditegaskan bahwa "yang dimaksud dengan perkawinan campuran dalam Undang-undang ini ialah perkawinan antara dua orang yang di Indonesia tunduk pada hukum yang berlainan, karena perbedaan kewarganegaraan dan salah satu pihak berkewarganegaraan Indonesia”. Jelaslah bahwa perkawinan lintas iman atau perkawinan orang-orang yang menganut agama yang berbeda di Indonesia memang tidak diakomodir dalam UU No.1 tahun 1974. Dengan kata lain, ada kekosongan hukum bagi warga Negara Indonesia yang mau menikah tetapi berbeda agama.

Oleh karena Undang-undang No.1 tahun 1974 tentang Perkawinan belum mengatur perkawinan campuran beda agama atau perkawinan campur lintas iman, maka ada alasan menggunakan Undang-undang yang lama yang mengatur perkawinan campur beda agama. Albert Hasibuan mengatakan bahwa kekosongan hukum yang mengatur dan mensahkan perkawinan antara orang berbeda agama dapat diatasi dengan menggunakan Undang-undang 
Kolonial, yaitu dengan melakukan tafsiran “A Contratio” terhadap UU No.1/1974 Pasal 66 yang mengatakan bahwa "untuk perkawinan dan segala sesuatu yang berhubungan dengan perkawinan berdasarkan atas undang-undang ini, maka dengan berlakunya Undang-undang ini, ketentuanketentuan yang diataur dalam Kitab Undang-undang sebelumnya dan perturan-peraturan lain yang mengatur tentang perkawinan, sejauh telah diatur dalam Undang-undang ini, dinyatakan tidak berlaku lagi. Karena perkawinan campur orang berbeda agama belum diatur, berarti undang-undang lama yang mengatur perkawinan campur yaitu Gemengde Huwelijken Regeling (GHR) masih tetap berlaku untuk melangsungkan perkawinan antar dua orang yang berbeda agamanya, yaitu dilaksanakan oleh Kantor Catatan Sipil. ${ }^{6}$ Pendapat serupa dikemukakan oleh Suharto bahwa penggunaan peraturan lama (GHR) dapat menjadi solusi mengatasi kekosongan hukum perkawinan campur agama berdasarkan "escape clausule" UU No. 1 tahun 1974 Pasal 66, yang intinya: hal-hal yang belum diatur di dalam Undang-undang ini dapat dipergunakan peraturan perundangan yang sudah ada sebelum berlakunya undang-undang ini. ${ }^{7}$ Dengan kata lain, karena perkawinan lintas iman atau kawin campur beda agama belum diatur, maka berlaku undang-undang yang lama.

GHR adalah Undang-undang Kolonial bernama Regeling op de Gemende Huwelijken atau yang lebih populer disebut Gemende Huwelijken Regeling (GHR), dalam bahasa Indonesia disebut Ordonansi Perkawinan Campuran Stb. 1898 No. 158 yang memang mengakomodir perkawinan campur beda agama atau perkawinman lintas iman. Pasal 1 menyebutkan: "Yang dinamakan perkawinan campuran ialah perkawinan antara orang - orang di Indonesia yang

\footnotetext{
${ }^{6}$ Albert Hasibuan, "Beberapa Pokok Pikiran tentang Penyelesaian Masalah Perkawian Campuran", dalam: Weinata Sairin dan J.M. Pattiasina (peny.), Pelaksanaan Undang-undang Perkawinan dalam Perspektif Kristen, Jakarta: BPK Gunung Mulia 1996, 80-81.

7 Suharto, "Beberapa Segi Hukum Perkawinan di Indonesia, Khususnya Perkawinan Campuran antara Agama", dalam: Weinata Sairin dan J.M. Pattiasina (peny.), Pelaksanaan Undang-undang Perkawinan dalam Perspektif Kristen, 91.
} 
tunduk pada hukum yang berlainan". ${ }^{8}$ Kemudian Pasal 7 ayat 2 yang berbunyi: "Perbedaan agama, suku, bangsa atau asal itu, sama sekali bukanlah menjadi halangan untuk perkawinan itu". ${ }^{9}$ Jelaslah kiranya bahwa Ordonansi Perkawinan Campuran Stb. 1898 No. 158 membuka kemungkinan untuk mengadakan perkawinan orang yang berbeda agama atau perkawinan lintas iman.

Menurut Sudargo Gautama, maraknya kasus-kasus perkawinan campuran di Indonesia pada waktu itu, menjadi alasan yang mendorong pemerintah Kolonial mengeluarkan Beslit Kerajaan (Koninklijk Besluit) pada tanggal 29 Desember 1896 nomor 23 yaitu Staatblad 1898 Nomor $158 .{ }^{10}$ Peraturan Perkawinan Campuran yang diundangkan tahun 1898 ini tidak mempersoalkan kewarganegaraan dan agama yang berkepentingan, yang penting dia adalah penduduk Indonesia. Padahal pada saat itu yang dianggap warga Negara adalah orang Belanda sedangkan orang Bumiputera dan Timur Asing dianggap orang asing. ${ }^{11}$ Dengan demikian, pada masa itu, banyaknya praktek perkawinan antara orang berbeda kewarganegaraan dan berbeda agama difasilitasi perkawinannya oleh Negara di mana realitas kemajemukan dalam masyarakat diakomodir dalam peraturan perundang-undangan.

Justeru setelah Indonesia merdeka sampai sekarang realitas kemajemukan, khususnya dalam perkawinan campuran lintas agama atau lintas iman, tidak lagi diakomodir dalam perundang-undangan sehingga pelaksanaannya dan pengesahannya sangat sulit dilaksanakan. R. Wirjono Prodjodikoro mengatakan bahwa pelaksanaan perkawinan campuran di Indonesia setelah kemerdekaan Indonesia menjadi sangat sulit dilaksanakan, khususnya kalau-laki-lakinya

${ }^{8}$ Lihat: K. Wantjik Saleh, Himpunan Peraturan dan Undang-undang tentang Perkawinan, Jakarta: Ikhtiar Baru - Van Hoeve, 1974, 9.

${ }^{9}$ K. Wantjik Saleh, Himpunan Peraturan dan Undang-undang tentang Perkawinan, 10.

${ }^{10}$ Sudargo Gautama, Segi-segi Hukum Peraturan Perkawinan Campuran (Staatblad 1898 Nomor 158), Bandung: Citra Aditya Bakti, 1996, 56.

${ }^{11}$ R. Soetojo Prawiromaidjojo, Pluralisme dalam Perundang-undangan Perkawinan di Indonesia, Surabaya: Airlangga University Press, 1988, 89. 
Islam, sebab Pegawai Pencatat Nikah (PPN) yang diatur dalam UU No. 22 tahun 1946 tentang Pencatatan Nikah, Talak dan Rujuk, justeru bertugas untuk mengawasi Akad Nikah yang dilakukan oleh orang-orang Islam dan mereka tidak mau melepaskan diri dari syarat mutlak dalam Hukum Islam bahwa seorang beragama Islam harus kawin dengan orang Islam juga. Maka ditemui kesulitan-kesulitan dalam mengadakan formalitas-formalitas perkawinan campuran tersebut. ${ }^{12}$ Sampai sekarang, sebagai dampak dari tiadanya hukum yang mengatur perkawinan campuran antara orang-orang berbeda agama secara jelas, maka perkawinan campuran semacam itu sangat sulit di laksanakan dan dilegalisasi.

Perkawinan lintas iman atau perkawinan campur agama tidak dapat dilayani oleh Negara, baik karena alasan Undang-undang No 1 tahun 1974 tentang Perkawinan, yang tidak mengakomodirnya, maupun karena sikap agama-agama yang tidak seragam dalam menangani kasus-kasus perkawinan campur lintas iman. Perkawinan lintas iman bukan hanya tidak diakomodir, malah cenderung pula dipersulit, baik oleh petugas Negara, maupun oleh petugas keagamaan. Berbagai upaya dilakukan oleh kelompok tertentu untuk memperjuangkan supaya Negara memfasilitasi perkawinan lintas iman karena realitas pluralitas warga Negara Indonesia dan karena Hak-hak Asasi manusia. Berikut disebutkan satu-dua contoh.

KAPAL perempuan (Lingkaran Pendidikan Alternatif untuk Perempuan) yang lahir dari komitmen beberapa aktivis yang mempunyai visi untuk turut mengembangkan pemikiranpemikiran kritis menuju terciptanya masayarakt yang berkeadilan social, berkeadilan gender, demokratis, dan pluralis, menginisiasi suatu upaya agar, kaum perempuan mendapatkan hak-hak yang sama dalam kehidupan berbangsa dan bernegara. Salah satu isu yang mereka perjuangkan sejak tahun 2000 adalah mempersoalkan upaya Negara dan Lembaga keagamaan yang

\footnotetext{
${ }^{12}$ R. Wirjono Prodjodikoro, Hukum Antar Golongan di Indonesia, Cet.7, Jakarta: Sumur Bandung, 1981, 92.
} 
mempersulit, atau bahkan melarang perkawinan campur lintas agama. Perjuangan ini dituangkan dalam salah satu buku yang diterbitkan dengan judul: "Tafsir Ulang Perkawinan Lintas Agama: Perspektif Perempuan dan Pluralisme". ${ }^{13}$ Salah seorang penulis dalam buku ini, Siti Musdah Mulia, menggaris bawahi bahwa menghadapi realitas pernikahan lintas agama di masyarakat, Negara harus mampu membuat regulasi yang mengartikulasikan kebutuhan serta memberikan kenyamanan bagi semua pihak di masyarakat. Untuk itu Negara segera melakukan tiga hal utama yaitu pertama, melakukan perubahan Kompilasi Hukum Islam yang terlegalisasi dalam Inpres Nomor 1 tahun 1991, kedua, merevisi UU No.1/1974 tentang Perkawinan dan membuat Undangundang Catatan Sipil, dan ketiga, mencabut sejumlah Fatwa MUI yang berkaitan dengan pernikahan, khususnya larangan pernikahan lintas Agama. ${ }^{14}$ Inisiatip ini tentu saja masih menghadapi perjuangan panjang.

Usaha Hukum pernah dilakukan oleh sejumlah alumni dan seorang mahasiswa Fakultas Hukum Universitas Indonesia yaitu Damian Agata Yuvens, Rangga Sujud Widigda, Varida Megawati Simarmata, dan Anbar Jayadi, menggugat sebagian isi Undang-undang nomor 1 tahun 1974 tentang perkawinan. Mereka mengajukan uji materi ke Mahkamah Konstitusi, terhadap satu pasal yang dianggap multitafsir sehingga merugikan calon mempelai pernikahan beda agama, yaitu Pasal 2 ayat 1 yang berbunyi: "Perkawinan adalah sah apabila dilakukan menurut hukum masing-masing agamanya dan kepercayaan itu." Menurut para pemohon, pasal ini menimbulkan ketidakpastian hukum, karena tidak jelas pihak yang diberikan kewenangan untuk menafsirkan hukum agama atau kepercayaan mana yang berlaku dalam perkawinan. Selain itu,

\footnotetext{
${ }^{13}$ Maria Ulfah Anshor \& Martin Lukito Sinaga (ed.), Tafsir Ulang Perkawinan Lintas Agama: Perspektif Perempuan dan Pluralisme, Jakarta: Kapal Perempuan 2004, vii. ${ }^{14}$ Maria Ulfah Anshor \& Martin Lukito Sinaga (ed.), Tafsir Ulang Perkawinan Lintas Agama: Perspektif Perempuan dan Pluralisme,131-134. Sebagai catatan, justru MUI memperkuat fatwa larangan perkawinan campur dengan menegaskan tahun 2005 bahwa perkawinan campur adalah haram.
} 
pengaturan pernikahan seperti tercantum dalam pasal 2 ayat 1 berimplikasi pada tidak sahnya pernikahan yang dilakukan di luar hukum masing-masing agama dan kepercayaannya. ${ }^{15}$ Walaupun mereka didukung oleh beberapa saksi ahli, gugatan mereka ditolak oleh Mahkamah Konstitusi.

Dalam Sidang tanggal 18 Juni 2015, Mahkamah Konstitusi menolak uji materi soal nikah beda agama terebut di atas dengan menegaskan bahwa larangan menikahi pasangan yang berbeda agama, seperti diatur dalam Undang-Undang Nomor 1 Tahun 1974 tentang Perkawinan, tidak melanggar konstitusi. Mahkamah Kontitusi menyatakan bahwa agama menjadi landasan bagi komunitas, individu, dan mewadahi hubungan dengan Tuhan Yang Maha Esa. Sedangkan negara berperan menjamin kepastian hukum serta melindungi pembentukan keluarga yang sah. Menurut hakim konstitusi, pasal bahwa perkawinan dianggap sah apabila dilakukan menurut masing-masing agama dan dicatat sesuai aturan perundangan, bukan pelanggaran terhadap konstitusi. ${ }^{16}$ Dengan demikian upaya uji coba materi terhadap larangan perkawinan lintas iman mengalami kegagalan.

Upaya lebih konkrit pernah dilakukan oleh Yayasan Wakaf Paramadina yang dibentuk oleh Almarhum Nurcholish Madjid. Mereka membuka diri untuk melayani perkawinan campur berbeda atau yang dikenal dengan istilah Nikah Beda Agama (NBA) dan sempat melayani puluhan pasangan kawin campur beda agama, tetapi rupanya usaha ini hanya seumur jagung. Menurut Ahmad Nurcholish, yang dilayani pernikahannya oleh Wakaf Paramadina, bulan Juni tahun 2003, pelayanan Wakaf Paramadina terhadap NBA berakhir tahun 2005, lalu diambil alih oleh The Wahid Institute (WI) lembaga yang didirikan oleh K.H. Abdurrachamn Wahid dan

\footnotetext{
${ }^{15}$ Sumber:http://www.bbc.com/indonesia/berita_indonesia/2014/12/141204_pernikahan_beda_agama, diakses 29 Mei 2017.

${ }^{16}$ Sumber: http://www.bbc.com/indonesia/berita_indonesia/2015/06/150618_indonesia_mk_nikah_bedaagama, diakses 29 Mei 2017.
} 
sempat juga memfasilitasi pernikahan beda agama tahun 2005, lalu dilanjutkan oleh Indonesian Conference on Religion and Peace (ICRP) yang dibentuk tahun 2005, tetapi pelayanan mereka yang bertajuk Advokasi keluarga Harmoni, bertahan hanya sampai Desember 2007 dan berhenti secara efektif Januari 2008. ${ }^{17}$ Berdasarkan pengalamnnya sebagai pasangan NBA, Ahmad Nurcholish menulis buku yang membela perkawinan campur berbeda agama dan memberikan banyak arahan bagi mereka yang mau melakukan perkawinan atau nikah beda agama di Indonesia. Sayang bahwa apa yang ditulis Ahmad Nurcholish sangat sulit dilakukan oleh Pejabat Negara.

\section{Sudut Pandang Teologi Agama-agama terhadap Nikah Lintas Iman}

Sulitnya layanan Negara dalam bentuk legalisasi hukum terhadap perkawinan lintas iman atau perkawinan campur oarng berbeda agama berlatarbelakang dalam teologi yang dianut agama-agama di Indonesia, khususnya agama yang diakui keberadaannya oleh Negara. Semua agama cenderung bersikap partikularistik dan eksklusif dalam pandangan teologinya, termasuk dalam pandangan teologi tentang perkawinan. Teologi agama-agama pada tataran teoritis cenderung bersikap inklusif dan pluralistik oleh karena menurut Harold Coward setiap agama muncul dalam lingkungan yang plural ditinjau dari sudut agama dan membentuk dirinya sebagai

\footnotetext{
${ }^{17}$ Mohammad Monib dan Ahmad Nurcholish, Kado Cinta bagi Pasangan Nikah Beda Agama, Jakarta: Gramedia Pustaka Utama, Cet 2, 2009, xxiii-xxiv
} 
tanggapan terhadap pluralisme tersebut. ${ }^{18}$ Namun dalam tataran praksis, agama-agama cenderung bersikap eksklusif.

Perjumpaan agama-agama di Indonesia di masa lalu ikut membentuk sikap eksklusif karena masing-masing agama merupakan agama misi atau dakwah. Aritonang mengemukakan bahwa salah satu masalah dalam perjumpaan Kristen dan Islam di Indionesia yang tidak terpecahkan sampai saat ini adalah masalah perkawinan antara antara dua orang yang berbeda agama, yang lazim disebut perkawinan campuran. ${ }^{19}$ Sikap defensif dan offensif agama-agama di Indonesia, khususnya Islam dan Kristen, menyebabkan perdebatan panjang dan tarik-ulur perlutidaknya perkawinan campuran atau perkawinan lintas iman diakomodir dalam Undang-undang perkawinan. Artinya, agama mengajarkan adanya kewajiban untuk menyiarkan dan menyebarkan agama kepada setiap orang. Hal ini, menurut Coward merupakan bagian dari hakikat kita sebagai manusia yaitu ingin membagi keyakinan kita yang paling berharga kepada orang lain. Kesulitan terjadi apabila keinginan dan perintah untuk menyebarkan ajaran sendiri untuk orang lain dibuat militan atau eksklusif. ${ }^{20}$ Kecenderungan inilah kiranya yang menjadi latarbelakang sikap menolak perkawinan lintas iman atau perkawinan campur orang-orang berbeda agama di Indonesia.

Latarbelakang lahirnya Undang-undang Nomor 1 tahun 1974, agak berbeda dengan latarbelakang lahirnya CHR yang mau mengakomodir realitas perkawinan lintas agama di Indonesia, justru lahirnya Undang-undang Nomor 1 tahun 1974 didorong oleh kekuatiran pada maraknya penyebaran agama oleh karena itu berusaha menutup kemungkinan perkawinan orangorang berbeda agama. Perkawinan dikuatirkan menjadi salah alat ekspansi agama tertentu, misalnya saja legalisasi perkawinan campuran dapat ditunggangi oleh kristenisasi terhadap umat

\footnotetext{
${ }^{18}$ Harold Coward, Pluralisme: Tantangan bagi Agama-agama, Yokyakarta, Kanisius, 1989,167.

19 J.S. Aritonang, Sejarah Perjumpaan Kristen dan Islam di Indonesia, Jakarta: BPK Gunung Mulia $2004,424$.

${ }^{20}$ Harold Coward, Pluralisme: Tantangan bagi Agama-agama, 173.
} 
beragama lain, khususnya Islam. Sebelum UU No. 1/1974 tentang perkawinan diundangkan, kalangan Islam tertentu menuding bahwa RUU ini adalah bagian dari Kristenisasi di Indonesia. ${ }^{21}$ Perkawinan campuran dikuatirkan menyebabkan terjadinya arus perpindahan agama atau konversi dari agama yang satu ke agama yang lain, khususnya konversi Islam yang mayorits penganutnya di Indonesia, menjadi Kristen melalui perkawinan.

Menurut pengamatan Weinata Sairin, dalam proses pembahasan Rancangan Undangundang perkawinan melibatkan masyarakat luas, termasuk lembaga-lembaga keagamaan, sehingga pasal yang mengatur tentang perkawinan campur RUU Pasal 11 ayat 2, menyebutkan:"perbedaan karena kebangsaan, suku bangsa, Negara asal, agama/kepercayaan dan keturunan, tidak merupakan penghalang perkawinan", ditolak oleh sebagian tokoh agama karena dianggap bertentangan dengan ajaran Islam, dan pada waktu itu, H. Rasjidi dalam harian Nusantara, 14 Agustus 1973, menyebutnya sebagai kristeniasi terselubung. ${ }^{22}$ Itu sebabnya pasal ini dihapus malah diganti dengan pasal tentang larangan perkawinan orang berbeda agama menurut Pasal 8 huruf (f) yang disebutkan di atas.

Menurut Leony Wijaya, dari ketentuan Pasal 8 huruf (f) tersebut dapat dilihat bahwa disamping ada larangan - larangan yang secara tegas disebutkan di dalam UU No. 1 Tahun 1974 Tentang Perkawinan dan peraturan - peraturan lainnya, juga ada larangan - larangan dari hukum masing - masing agamanya. ${ }^{23}$ Larangan dari masing-masing hukum agama tidak serupa sebab ada yang melarang dalam bentuk ajaran lisan atau mengaturnya dalam bentuk himbauan kepada

\footnotetext{
21 J.S. Aritonang, Sejarah Perjumpaan Kristen dan Islam di Indonesia, 406.

${ }^{22}$ Weinata Sairin dan J.M. Pattiasina (peny.), Pelaksanaan Undang-undang Perkawinan dalam Perspektif Kristen, 5.

${ }^{23}$ Sumber: Leony Wijaya "Sahnya Perkawinan Beda Agama Ditinjau dari Undang - Undang Nomor 1 Tahun 1974 dan Agama -Agama di Indonesia”, Posted on MARCH 18, 2016 , https://anastasyaleony.wordpress.com/2016/03/18/sahnya-perkawinan-beda-agama-ditinjau-dari-undang-undangnomor-1-tahun-1974-dan-agama-agama-di-indonesia/, diakses 29 Mei 2017.
} 
umat, tetapi ada juga yang melarang dalam bentuk hukum formal. Dari 6 Agama yang diakui keberadaannya di Indonesia, yang memberikan larangan yang tegas adalah Islam. Menurut Asmin, dalam Alquran dengan tegas dilarang adanya perkawinan karena perbedaan agama (Quran II:221), kecuali bagi laki-laki Muslim. Seorang laki-laki Muslim dihalalkan mengawini wanita non-Muslim asalkan dia dari golongan kitabiyah (ahli kitab yaitu Yahudi dan Nasrani) [Quran V:5]. ${ }^{24}$ Oleh sebab itu syarat-syarat nikah yang dicantumkan pada nomor 1 , baik bagi calon mempelai laki-laki maupun mempelai perempuan adalah beragama Islam.

Larangan perkawinan campur beda agama secara legal dipertegas oleh fatwa Majelis Ulama Indonesia tahun 1980 dan diperbarui tahun 2005 dimana ditegaskan bahwa: 1. Perkawinan beda agama adalah haram dan tidak sah. 2. Perkawinan laki-laki Muslim dengan wanita Ahlu Kitab, menurut qaul mu'tamad adalah haram dan tidak sah. ${ }^{25}$ Dengan adanya fatwa MUI tersebut maka otomatis tertutup kemungkinan bagi seorang Muslim menikah dengan orang dari Agama lain. Lembaga Agama Islam besar di Indonesia seperti NU dan Muhammadiyah juga melarang perkawinan campur. Ulama Nahdlatul Ulama (NU) telah menetapkan fatwa terkait nikah campur berbeda agama. Fatwa itu ditetapkan dalam Muktamar ke-28 di Yogyakarta pada akhir November 1989. Ulama NU dalam fatwanya menegaskan bahwa nikah antara dua orang yang berlainan agama di Indonesia hukumnya tidak sah. Majelis Tarjih danTajdid PP Muhammadiyah juga telah menetapkan fatwa tentang pernikahan berbeda agama. Secara tegas, ulama Muhammadiyah menyatakan bahwa seorang wanita Muslim dilarang menikah dengan pria non-Muslim. Hal itu sesuai dengan sura al-Baqarah ayat 221. "Berdasarkan ayat tersebut, lakilaki Mukmin juga dilarang nikah dengan wanita non-Muslim dan wanita Muslim dilarang walinya untuk menikahkan dengan laki-laki non-Muslim," ungkap ulama Muhammadiyah dalam

\footnotetext{
${ }^{24}$ Asmin, Status Perkawinan Antar Agama, ditinjau dari Undang-undang No.1/1974, Jakarta: Penerbit Dian Rakyat 1986, 33.

${ }^{25}$ Majelis Ulama Indonesia, Fatwa Munas VII Majelis Ulama Indonesia, Jakarta: MUI, 2005, 23.
} 
fatwanya. ${ }^{26}$ Walaupun banyak pendapat yang berbeda-beda mengenai larangan perkawinan campur menurut Islam, secara garis besar harus diakui bahwa Islam di Indonesia melarang perkawinan lintas agama atau lintas iman dan itu yang mengakibatkan tidak diakomodirnya perkawinan lintas iman dalam Undang-undang perkawinan.

Bagaimana dengan agama lainnya? Harus diakui bahwa semua agama secara teologis melarang, atau sekurang-kurangnya, menganjurkan dan mengajarkan warganya supaya mencari pasangan hidup yang seagama. Gereja Katolik menerima perkawinan antara laki-laki dan perempuan yang dibaptis sebagai sakramen tanda yang menghadirkan rahmat keselamatan. ${ }^{27}$ Pernikahan yang ideal adalah pernikahan yang bersifat sakramen itu. Meskipun tidak ideal, gereja Katolik memberi kemungkinan adanya kawin campur yang bukan sakramen dengan segala persyaratannya. Perkawinan campur adalah perkawinan berbeda gereja dan berbeda agama. Perkawinan campur berbeda agama diberikan dispensasi. Dalam arti yuridis, menurut Al. Andang, berarti pembebasan dari hukum secara implisit mengandaikan larangan lebih berat. ${ }^{28}$ Walaupun ada dispensasi, sebenarnya gereja Katolik tidak dapat menerima perkawinan campur terutama berbeda agama dengan alasan adanya tanggung jawab gereja atas keselamatan. Lagi pula gereja Katolik berkeyakinan mempunyai iman sebagai kebenaran lebih penuh dari pada agama-agama atau gereja-gereja lain tang tidak menerima pelbagai kebenaran yang diaanggap cukup penting oleh gereja katolik. ${ }^{29}$ Walaupun demikian, situasi masyarakat dunia yang terus

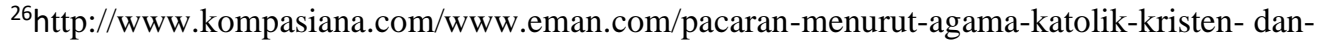
islam_54f35887745513792b6c71d1, diakses 27 Mei 2017

27 Johannes H. Haryanto, "Perkawian Beda Agama dalam pandangan Gereja Katolik", dalam: Maria Ulfah Anshor \& Martin Lukito Sinaga (ed.), Tafsir Ulang Perkawinan Lintas Agama: Perspektif Perempuan dan Pluralisme, 65.

${ }^{28}$ Al. Andang I. Binawan, Perkawinan Campur Beda Agama dalam Pandangan Katolik, http://www.ststefanus.or.id/artikel/artikel-bebas/pernikahan-campur-beda-agama-dalam-pandangan-katolik/, diakses 27 Mei 2017

${ }^{29}$ Piet Go dan Suharto, Kawin Campur Beda Agama dan Beda Gereja, Malang: Penerbit Dioma, 1990, 33-34.
} 
berkembang menyebabkan Gereja Katolik meninjau posisi dan sikap gereja terhadap kawin campur menurut Kitab Hukum Kanonik (KHK) Nomor 1093 tahun 1983, kanon 1124-1129 dan 1086. Kawin campur berbeda gereja tidak dimasukkan kategori halangan nikah tetapi membutuhkan ijin dari waligereja. Sedangkan kawin campur berbeda agama merupakan halangan tetapi dapat diberikan dispensasi dan diberkati menurut tata peneguhan kanonik dan diberikan penggembalaan khusus. ${ }^{30}$ Itu sebabnya perkawinan campur dapat dilakukan oleh dan di gereja Katolik.

Perkawinan orang Kristen di Indonesia dari masa Kolonial sampai sekarang sebenarnya masih tunduk pada Hukum Kolonial, sekurang-kurangnya dalam praktek. Ini disebabkan tidak jelasnya pengaturan legalisasi perkawinan orang Kristen dalam UU No.1/1974. Mengacu pada Pasal 2 (1) tentang sahnya perkawinan, situasi Gereja-gereja Kristen agak rancu. Di satu pihak gereja melakukan upacara pemberkatan dan peneguhan perkawinan dan mengaturnya dalam Tata Dasar atau Tata Gereja, tetapi dipihak lain yang mensahkan perkawinan orang Kristen adalah Kantor Catatan Sipil (sekarang disebut Dinas Kependudukan dan Catatan Sipil). Jadi bagi perkawinan orang Kristen yang dimaksud Pasal 2:1 tersebut bukan Tata Gereja melainkan hukum yang mengatur pengesahan perkawinan Kristen oleh hukum Negara yang dilaksanakan oleh Kantor Dinas Kependudukan dan Catatan Sipil.

Agama Kristen tidak mempunyai hukum perkawinan seperti yang dimiliki oleh Agama Islam atau Kitab Hukum Kanonik (KHK) yang dimiliki oleh Gereja Katolik. Oleh karena itu yang dimaksud dengan hukum agama bagi orang Kristen, bukanlah Peraturan Gereja atau Tata Gereja yang mengatur upacara pemberkatan dan peneguhan perkawinan di gereja, melainkan

\footnotetext{
${ }^{30}$ Piet Go dan Suharto, Kawin Campur Beda Agama dan Beda Gereja, 49 dan 102.
} 
Undang-undang yang mengatur tentang Pencatatan Perkawinan. Segera setelah Undang-undang No.1/1974 tentang Perkawinan diundangkan, maka diterbitkan Peraturan Pemerintah Nomor 9 tahun 1975 pada tanggal 1 April 1975 tentang Pelaksanaan UUP. Dalam Pasal 2 (2) ditegaskan bahwa:"pencatatan perkawinan dari mereka yang melangsungkan perkawinannya menurut agamanya dan kepercayaannya itu selain agama Islam, dilakukan oleh Pegawai pencatat perkawinan pada Kantor Catatan Sipil sebagaimana dimaksud dalam berbagai perundangundangan mengenai percatatan perkawinan". ${ }^{31}$ Ketentuan ini menimbulkan pertanyaan tentang siapakah yang mensahkan perkawinan agama lain selain Islam?

Dalam pelaksanaan perkawinan Kristen pada prinsipnya yang mensahkan secara legal formal adalah Negara melalui Kantor Catatan Sipil karena walaupun gereja menerbitkan Surat Nikah Gereja, Surat Nikah tersebut tidak dianggap sebagai Akta yang mensahkan perkawinan orang Kristen. Surat nikah yang sah adalah Akta Perkawinan yang diterbitkan oleh pemerintah, yaitu Kantor Catatan Sipil. Menurut Fridolin Ukur, dalam tata administrasi pemerintahan, seseorang baru dianggap sah pernikahannya (baca: perkawinannya) apabila dia dapat menunjukkan kutipan Akta Perkawinannya dari Kantor Dinas Kependududkan dan Catatan Sipil dan bukannya Surat Perkawinan Gereja. ${ }^{32}$ Hal ini sejalan dengan yang dikatakan Sudarto bahwa dalam praktek lalu lintas hukum, khususnya hubungannya dengan tata administrasi pemerintah, seseorang baru dianggap sah perkawinannya jika dapat menunjukkan kutipan Akta Perkawinannya dari Kantor Dinas Kependudukan dan Catatan Sipil. Menurut Sudarto, di Kantor Dinas Kependudukan dan Catatan Sipil, Pejabat yang bersangkutan tidak sekedar mencatat dan memasukkan ke dalam buku register perkawinan, melainkan Pejabat yang bersangkutan juga

\footnotetext{
31 Lihat: Asmin, Status Perkawinan Antar Agama, ditinjau dari Undang-undang No.1/ 1974, 119.

32 Fridolin Ukur, "Problematika Pelaksanaan Perkawinan di Indonesia dalam Pengamatan PGI", dalam: Weinata

Sairin dan J.M. Pattiasina (peny.), Pelaksanaan Undang-undang Perkawinan dalam Perspektif Kristen, 12.
} 
sekaligus meneguhkan perkawinan dengan mengucapkan kalimat atas nama Undang-undang: "kedua belah pihak sudah diteguhkan nikahnya". ${ }^{33}$ Dengan demikian harus dikatakan bahwa sahnya perkawinan di kalangan orang Kristen adalah berdasarkan hukum dan peraturan Negara, dalam hal itu pencatatan sipil yang dibuktikan oleh Akta Perkawinan.

Dengan pemahaman dan praktek demikian maka yang dimaksud dengan Pasal 2 Undang-undang No. 1 tahun 1974 tentang sahnya perkawinan bagi orang Krsiten, bukan hukum agama dalam arti Tata Gereja dan bukan melalui praktek Pemberkatan dan Peneguhan perkawinan di Gereja, melainkan melalui pelaksanaan perkawinan oleh Pejabat Pencatat perkawinan dari Kantor Dinas Kependudukan dan Catatan Sipil. Dalam hal itu pelaksanaan pengesahan perkawinan Kristen sesungguhnya masih mengacu kepada Ordonansi Perkawinan Indonesia-Kristen Jawa, Minahasa dan Ambon (Huwelijke Ordonantie voor Christen Indinesiers Java, Minahasa en Amboina [HOCI] Stbl. 1933/74 dan Stbl. 1933/75) tentang perkawinan golongan Kristen dan pencatatannya di Kantor Catatan Sipil, sesuai dengan Pasal 19-33, yang hanya dipertegas oleh PP Nomor 9 tahun 1974, Pasal 2 (2) seperti dikutip di atas.

Sangat jelas secara eksplisit disebutkan bahwa yang meresmikan perkawinan adalah Pegawai Pencatat perkawinan, yaitu setelah penandatanganan akta perkawinan. Dalam Bab III Pasal 11 nomor 1-3 diatur bahwa (1) kedua mempelai menandatangani akta perkawinan yang telah disiapkan oleh Pegawai Pencatat perkawinan, (2) kemudian akta perkawinan yang telah ditandatangani oleh kedua mempelai ditandatangani oleh saksi dan Pegawai Pencatat perkawinan. (3) Dengan penandatanganan akta perkawinan, maka perkawinan telah tercatat

\footnotetext{
${ }^{33}$ Sudarto, "Beberapa Segi Hukum Perkawinan di Indonesia, khususnya Perkawinan Campuran antar Agama", dalam: Weinata Sairin dan J.M. Pattiasina (peny.), Pelaksanaan Undang-undang Perkawinan dalam Perspektif Kristen, 87.
} 
secara resmi. Walaupun menggunakan kata "tercatat", harus diakui bahwa peresmian perkawinan itu dilakukan oleh pemerintah atas perintah undang-undang dan bukan oleh lembaga agama.

Walaupun gereja telah memberkati dan meneguhkan perkawinan pasangan, perkawinan itu belum resmi sebelum diresmikan oleh pemerintah, dalam hal itu Pegawai Pencatat perkawinan dan dibuktikan oleh adanya Akta Perkawinan. Surat Nikah yang diterbitkan oleh gereja, hanya berlaku secara internal dan tidak menjadi jaminan resminya perkawinan secara hukum. Urusan apapun dilakukan yang terkait dengan perkawinan tanpa Akta Perkawinan yang diterbitkan oleh pemerintah, maka urusan itu tidak bisa dilakukan. Adalaah ironis bahwa perkawinan orang Kristen selalu dianggap diresmikan oleh pemberkatan dan peneguhan, tetapi secara legal formal, Surat Nikah yang diterbitkan oleh gereja dianggap tidak legal, tidak resmi. Hal ini menimbulkan dualisme sekaligus paradox peresmian perkawinan orang Kristen. Di satu pihak, gereja diakui memiliki hukum perkawinan, tetapi di lain pihak, Surat Perkawinan yang diterbitkan oleh gereja tidak diakui sebagai bukti resmi dari perkawinan yang diselenggarakan gereja.

Mengacu kepada peraturan dan hukum perkawinan orang Kristen yang disebutkan di atas, maka gereja hanya memberkati dan meneguhkan perkawinan umatnya yang telah disahkan atau diresmikan oleh Negara melalui Catatan Sipil dan setelah memiliki Akta Perkawinan. Itu sebabnya, Persekutruan Gereja-gereja di Indonesia melalui Ketetapan Sidang Majelis Pekerja Lengkap (MPL-PGI) Nomor 01/MPL-PGI/1989 mengenai Pemahaman Gereja-gereja di Indonesia tentang Sahnya Perkawinan dan Perkawinan bagi Warga Negara yang Berbeda Agama, menandaskan bahwa perkawinan adalah sah, apabila dilakukan terlebih dahulu dihadapan Pejabat Kantor Dinas Kependudukan dan Catatan Sipil kemudian diteguhkn dan 
diberkati oleh gereja. ${ }^{34}$ Demikian juga perkawinan bagi yang berbeda agama mestinya bisa dilaksanakan di Kantor Dinas Kependudukan dan Catatan Sipil, kemudian pemberkatan dapat dilakukan oleh gereja sesuai peraturan yang berlaku dalam gereja yang bersangkutan. ${ }^{35}$ Mengapa Gereja Kristen (Protestan) tidak dapat meresmikan perkawinan orang berbeda agama bahkan warga jemaatnya sendiri?

Reformasi menolak ajaran Gereja Katolik yang mengatakan bahwa perkawinan adalah suatu sakramen. ${ }^{36}$ Martin Luther menyangkal bahwa pernikahan adalah sakramen yang ditetapkan Kristus. ${ }^{37}$ Luther menghargai cinta diantara dua orang yang berbeda secara seksual sebagai suatu cinta terbesar dan termurni. Namun dosa membuat cinta ini tidak lagi murni dan manusia cenderung mencari kepuasan dirinya masing-masing. Pernikahan adalah cara mengendalikan seksualitas yang telah dinodai oleh dosa dengan membuat struktur dan pembatasan. Tanpa pernikahan hubungan seksual akan mengarah kepada perzinahan yang tidak hanya akan menghancurkan jiwa tetapi juga tubuh, harta, kehormatan dan persahabatan. Jadi pernikahan adalah suatu tata ciptaan dan setelah kejatuhan ke dalam dosa menjadi cara untuk melindungi manusia melawan kuasa yang merusak seksualitas yang tidak terkendalikan. ${ }^{38}$ Walaupun Luther menolak usaha merohanikan pernikahan menjadi sakramen Kristen, tidak berarti bahwa ia menganggap remeh pernikahan. Luther tidak menyangkal bahwa pernikahan mempunyai dimensi rohani, segi itu tetap ditangani oleh gereja melalui pemberkatan pernikahan. ${ }^{39}$ Pernikahan memang bukan sakramen, namun demikian pernikahan berakar dengan

\footnotetext{
${ }^{34}$ Weinata Sairin dan J.M. Pattiasina (peny.), Pelaksanaan Undang-undang Perkawinan dalam Perspektif Kristen, 148.

${ }^{35}$ Weinata Sairin dan J.M. Pattiasina (peny.), Pelaksanaan Undang-undang Perkawinan dalam Perspektif Kristen, 150.

36 J.L. Ch. Abineno, "Peneguhan dan Pemberkatan Nikah", dalam: Weinata Sairin dan J.M. Pattiasina (peny.), Pelaksanaan Undang-undang Perkawinan dalam Perspektif Kristen, 23.

${ }^{37}$ Christiaan de Jonge, Apa itu Calvinisme, Jakarta: BPK Gunung Mulia, 2011, 246.

38 Paul Althaus, The Ethics of Martin Luther, Philadelphia: Fortress Press, 1973, 84

${ }^{39}$ Christiaan de Jonge, Apa itu Calvinisme, 147.
} 
kuat di dalam kehendak Allah Pencipta sebagai salah satu peraturan ilahi. Walaupun pernikahan bukan sakramen di dalam gereja, pernikahan adalah panggilan sosial yang lebih tinggi di dalam mana orang Kristen melatih imannya mengasihi keluarganya dan sesamanya manusia.Pernikahan memang bukan sakramen tetapi mencerminkan cinta yang mendalam dari Kristus terhadap gereja. Luther menganggap pernikahan sebagai suatu kejadian sekuler karena berurusan dengan realitas penciptaan dan bukan dengan penebusan. Maka pernikahan diatur oleh hukum Allah bukan oleh Injil. Pernikahan harus disahkan bukan oleh hukum gereja tetapi oleh hukum sipil.

Pandangan Martin Luther yang demikian menjadi dasar reformator yang lain membuat pemisahan tentang bagian yang menjadi tugas gereja dan bagian yang menjadi tugas Negara terhadap pernikahan. Menurut J. Verkuyl, ada dua macam motif sikap para reformator tersebut. Pertama, pandangan tentang perbedaan panggilan Negara dan panggilan gereja terhadap perkawinan. Kewajiban Negara ialah memberikan kekuatan hukum kepada pernikahan. Kewajiban gereja ialah memohon berkat Tuhan untuk pernikahan dan memberi pertolongan rohani kepada mereka yang menikah. Kedua, untuk menghindari paksaan keagamaan dalam perkawinan. Jika gereja menjadi satu-satunya instansi yang mengakui dan mensyahkan perkawinan, maka ada kemungkinan bahwa mereka yang menikah mengambil suatu keputusan keagamaan, terpaksa memeluk satu agama. Para reformator berpendapat bahwa harus ada kemungkinan menikah di Kantor Pencatatan Sipil tanpa peneguhan kegerejaan. ${ }^{40}$ Artinya sikap para reformator ini mempertimbangkan kemungkinan bahwa orang berbeda agama menikah dan dalam hal itu Negara berkewajiban mensahkan perkawinan mereka.

\footnotetext{
${ }^{40}$ J. Verkuyl, Etika Kristen: Seksual, Cet. Ke 5, Jakarta: BPK Gunung Mulia, 1987, 124.
} 


\section{Sudut Pandang Etika tentang Perkawinan Lintas Iman}

Apakah Etika? Dalam pengertian modern etika disebut sebagai sistem standar kehidupan yang mengatur perilaku atau tindakan manusia. Etika, menurut Eka Darmaputera, adalah ilmu atau studi mengenai norma-norma yang mengatur kehidupan manusia. ${ }^{41}$ Etika mempersoalkan apa yang baik, benar dan patut dalam interaksi manusia. Ada banyak hal yang berurusan dengan perilaku etis, misalnya soal hak dan kebebasan, yang dimiliki oleh setiap orang. Bagaimana hak dan kebebasan itu dilihat dari sudut pandang perilaku pribadi maupun institusi. Dalam hal itu, perilaku etis menuntut adanya kemampuan untuk menerima dengan akal dan untuk mengerti akibat-akibat yang ditimbulkan keputusan-keputusan tentang tindakan seseorang atau sebuah institusi. Demikianlah masalah nikah lintas agama atau masalah perkawinan campur berbeda agama tidak hanya berurusan dengan perilku individu tetapi juga kaitannya dengan perilaku yang bersifat institusi terutama dalam hal sikap dan keputusan-keutusan yang dil;andaskan pada hukum legal atau norma-norma hukum berhadapoan dengan norma-norma moral.

Perkawinan, sebagaimana ditegaskan dalam DUHAM dan UUD 45 sebagaimana disebutkan dalam bagian Pendahuluan tulisan ini, adalah hak dan kebebasan setiap orang berdasarkan kesepakatan dua orang yang mau menikah. Tinjauan etika terhadap pernikahan lintas iman dimulai dengan titik tolak hak dan kebebasan. Etika berbicara tentang hak dan kebebasan setiap orang untuk hidup dan berkeluarga sesuai harkat dan martabat yang melekat padanya sebagai manusia. Pilihan setiap orang sesuai hak dan kebebasan asasinya tidak seharusnya dihalangi oleh orang lain ataupun institusi sejauh tidak mengakibatkan kerugian bagi orang lain atau bagi masyarakat. Kovenan Internasional Hak Sipil dan Politik, Pasal 23 ayat 2-3 menggaris bawahi (2) hak laki-laki dan perempuan dewasa untuk menikah dan membentuk satu

\footnotetext{
${ }^{41}$ Eka Darmaputera, Etika Sederhana untuk Semua, Jakarta: BPK Gunung Mulia, 1987, 5.
} 
keluarga harus dihargai, (3) tidak ada perkawinan yang dapat dilakukan tanpa persetujuan yang bebas dan penuh dari kedua calon mempelai. ${ }^{42}$ Hak dan kebebasan kedua mempelai menetukan apapun yang menjadi pilihan mereka untuk menikah, termasuk pilihannya untuk menikah berbeda agama dan mempertahanlan agama masing-masing, harus dihargai oleh setiap orang, lembaga agama dan Negara. Sebaliknya, setiap orang, lembaga agama dan Negara wajib mendukung kedua orang yang menikah untuk memudahkan dan memperlancar pelaksanaan perkawinan mereka. Perkawinan lintas iman atau perkawinan campur berbeda agama memperhadapkan etika individu (khususnya penggunaan hak dan pilihan bebas), dengan norma legal negara (Undang-undang perkawinan) dan Peraturan-peraturan agama.

Apakah hak? Menurut Kees Bertens, dalam pemikiran para Filsuf Yunani Kuno, arti hak belum dapat didefenisikan dalam arti yang sebenarnya. Kata hak masih menunjuk kepada arti hukum secara objektif: undang-undang, aturan-aturan dan lembaga-lembaga yang mengatur kehidupan masyarakat demi kepentingan umum. ${ }^{43}$ Baru pada akhir abad 17 dan dalam abad 18 muncul pengertian hak dalam arti modern yang berkaitan dengan kebebasan manusia, terlepas dari setiap ikatan dengan hukum objektif. Kebebasan dan otonomi manusia telah diakui. ${ }^{44}$ Hak adalah klaim yang sah dari seseorang sebagai manusia untuk diperlakukan oleh orang lain. Hak ini timbul sebagai bagian dari harkat dan martabat setiap orang sebagai manusia. Dari pengertian ini nampak jelas bahwa hak orang-orang yang menikah dengan orang berbeda agamanya harus dihargai dan diperlakukan dengan semestinya, dilindungi secara hukum.

Biasanya dibedakan dua macam hak, yaitu hak legal dan hak moral. Hak legal adalah hak yang didasarkan atas hukum dalam salah satu bentuk, yang berasal dari undang-undang,

\footnotetext{
42 PaxBenedanto (ed.), Kovenan Internasional Hal Sipil dan Politik, Jakarta: Lembaga Studi Pers \& Pembangunan, 2000, 79.

${ }^{43}$ Kees Bertens, Etika, Jakarta: PT. Gramedia Pustaka Umum, 2004, 177.

${ }^{44}$ Kees Bertens, Etika, 178
} 
peraturan hukum dan dokumen legal lainnya. Hak ini didasarkan atas prinsip hukum. Dilain pihak, hak moral berfungsi dalam sistem moral dengan didasarkan atas prinsip etis saja. Walaupun keduanya sering dianggap saling terkait namun tidak selamanya saling berhubungan, bahkan kadangkala berhadap-hadapan. Tidak selamanya hak-hak legal merupakan hak-hak moral, dan banyak hak-hak moral yang diterapkan dan dihidupkan hanya sebatas hak-hak moral dan tidak menjadi hak legal. ${ }^{45}$ Memang, idealnya apabila hak legal merupakan hak moral juga. Hak-hak legal sepatutnya memiliki kekuatan moral. Demikian pula hak-hak moral lebih terasa efektif dan memiliki kedudukan yang kokoh dalam masyarakat, jika didukung dan dilindungi oleh status hukum. Perkawinan campur orang yang berbeda agama, mengandung baik hak legal maupun hak moral, dan hak moral yang seharusnya didukung dan dilindungi oleh hukum supaya keduduklan mereka dalam masyarakat menjadi kuat juga. Disinilah juga kita melihat hubungan erat antara hak dan kebebasan warga Negara dalam mengaktualisasikan dirinya, antara lain melalui perkawianan atas dasar pilihan bebas.

Franz Magnis-Suseno mengatakan, apabila kita mendengar kata kebebasan, yang pertama-tama kita pikirkan adalah bahwa orang lain tidak memaksa kita untuk melakukan sesuatu melawan kehendak kita. Kita bebas apabila masyarakat tidak menghalang-halangi kita untuk berbuat apa yang ingin kita lakukan. Namun, kata bebas masih mempunyai arti yang lebih mendasar, yaitu kita mampu untuk menentukan sendiri, apapun yang mau kita lakukan. ${ }^{46}$ Itulah aktualisasi diri yaitu perwujudan hak dan kebebasan di tengah masyarakat. Namun hak dan kebebasan yang diberikan oleh orang lain, pun yang diberikan oleh Negara memang harus disertai tanggung jawab sebagai cara menghargai hak dan kebebasan itu.

\footnotetext{
45 Peter Singer, (ed.), A Companion To Ethics, Massachusetts: Blackwell, 1997, 216.

${ }^{46}$ Franz Magnis Suseno, Etika Dasar: Masalah-Masalah Pokok Filsafat Moral, Yogyakarta: Kanisius, $1987,22$.
} 
Kebebasan dibedakan dalam dua arti, yaitu kebebasan eksistensial dan kebebasan sosial. Kebebasan eksistensial pada hakikatnya merupakan kemampuan manusia untuk menetukan dirinya sendiri. Sifatnya positif, artinya kebebasan untuk tidak menekankan segi bebas dari apa, tetapi bebas untuk apa. Kita sanggup untuk menentukan tindakan kita sendiri. Kebebasan itu mendapat wujudnya yang positif dalam tindakan kita yang disengaja. Tidak setiap kegiatan manusia merupakan tindakan. Tindakan dilakukan dengan maksud dan tujuan tertentu, dengan kesadaran bahwa tergantung pada kitalah apakah kegiatan itu dilakukan atau tidak. Kebebasan eksistensial mengandung makna jasmani dan rohani. Kebebasan jasmani bagi manusia pertamatama berarti, bahwa ia dapat menentukan apa yang mau dilakukannya secara fisik, sedangkan kebebasan rohani adalah kemampuan kita untuk menentukan sendiri apa yang kita pikirkan untuk menghendaki sesuatu. ${ }^{47}$ Jadi, kebebassan ekstensial adalah kemampuan manusia untuk menentukan tindakanya sendiri. Kemampuan itu bersumber pada kemampuan manusia untuk berpikir, berkehendak, dan terwujud dalam tindakan. Namun apakah tindakan itu? Tindakan itu bukan sesuatu diluar manusia. Tindakan adalah satu dengan diri saya sendiri. Dalam tindakan diri saya sendiri bertindak, diri saya sendiri yang terlibat. Saya menjadi diri saya melalui tindakan saya. Maka kebebasan eksistensial tidak hanya berarti bahwa saya menetukan tindakan saya, melainkan melalui tindakan saya menentukan diri saya sendiri. ${ }^{48}$ Bagaimanakah kebebasan eksistensial ini bisa ini benar-benar diwujudkan?

Di sinilah pertanayaan etis muncul, karena kebebasan eksistensial manusia tidak selalu dapat diwujudkan karena dibatasi oleh orang lain atau institusi. Itulah sebabnya mengapa kebebasan eksistensial biasanya kita hayati dalam hubungan dengan orang lain. Setiap orang berjuang untuk membela kebebasan terhadap usaha orang lain untuk membatasinya. Manusia itu

\footnotetext{
${ }^{47}$ Franz Magnis Suseno, Etika Dasar, 23.

${ }^{48}$ Franz Magnis Suseno, Etika Dasar, 26.
} 
bebas apabila kemungkinan-kemungkinannya untuk bertindak tidak dibatasi oleh orang lain. Karena kebebasan itu secara hakiki dihayati dengan orang lain, maka kebebasan eksistensial berhadapana dengan yang disebut dengan kebebasan social, kebebasan di tengah masuysrakat. Pembatasan kebebasan dapat melalui larangan dan perintah. Larangan kawin dengan orang beragama lain adalah contoh paling nyata dari pembatasan kebebasan eksistensial berhadapan dengan kebebasan sosial. Pertanyaan yang muncul adalah apakah larangan terhapadap pilihan bebas sesuai hak yang melekat pada setiap orang untuk menikah dengan orang dari lain agama dapat dibenarkan menurut etika?

Etika bukan sekedar pengetahuan melainkan juga sebagai pengejewantahan moral Apakah Moral? Istilah moral pertama kali dipergunakan oleh Cicero (106-43 B.C.) ${ }^{49}$ yang diartikannya sebagai kebiasaan baik yang dinyatakan dalam kelakuan, umpamanya bahwa mengatakan yang benar itu adalah sesuatu yang baik. Istilah moral diturunkan dari kata Latin mos (jamak mores) artinya semua yang baik dan benar yang berlaku dalam masyarakat. Dalam bahasa Indonesia, kata moral cocok diterjemahkan dengan kata susila (bahasa Sansekerta su atinya baik, dan sila artinya dasar atau norma). Jadi susila berarti norma kebaikan dalam masyarakat. Kesusilaan adalah keseluruhan aturan, kaidah atau hukum yang mengambil bentuk perintah dan larangan. Kesusilaan atau moral menanamkan kebajikan dan kewajiban melalui pengajaran dan keteladanan, individu maupun institusi.

Tinjauan etika terhadap perkawinan lintas iman atau perkawinan campur orang berbeda agama menyoroti dua aspek, yaitu moral institusi dan moral individu. Pertama, moral institusi terkait dengan sikap mempersulit dan/atau mengahalangi warga masyarakat menikah karena

\footnotetext{
${ }^{49}$ Horace Abram Riogg, Jr, "Primitive Morals", in Vergilius Ferm (ed.), Encyclopedia of Morals, New York: Philosophical Morals, 1956, 434
} 
berbeda agama atau keyakinan. Institusi Negara dan agama dapat dipandang melakukan tindakan tidak bermoral kalau mempersulit dan/atau menghangi warga Negara atau umat beragama dalam mewujudkan hak dan kebebasannya. Perwujudan hak dan kebebasan dalam memilih pasangan hidup merupakan nilai moral yang harus dihargai dan dijunjung tinggi. Oleh karena itu, instansi hukum dan agama yang menghalangi atau mempersulit perwujudan hak dan kebebasan tersebut dapat dikategorikan sebagai tindakan tidak bermoral dari institusi Negara dan agama.

Sikap Negara, melalui hukum legal, yang mempersulit dan mengabaikan pemberian hakhak sipil warga Negara yang melakukan perkawinan campur berbeda agama adalah pelanggaran moral, yang seharusnya menjadi kewajiban setiap penyenggara Negara. Pelanggaran moral itu nampak dari sikap mempersulit atau mengabaikan hak-hak sipil warga Negara, misalnya tidak melayani pencatatan sipil dan mempersulit atau mengabaikan Akta Nikah. ${ }^{50}$ Pada gilirannya, sikap mempersulit dan mengabaikan hak-hak dan kebebasan setiap warga Negara memilih pasangan hidupnya, berdampak pada moral individu.

Manusia adalah makhluk yang memutuskan (animal iudicans), demikian Adelbert Snijders. ${ }^{51}$ Maka keputusan tiap orang yang dibuat dengan hati nuraninya harus dihargai. Memang betul bahwa setiap orang harus menghormati norma-norma yang berlaku, tetapi sebaliknya, keputusan pribadi berdasarkan pilihan harus dihormati, baik oleh individu yang lain maupun institusi. Adanya pembatasan terhadap keputusan individu berdasarkan hak dan kebebasannya dalam memilih pasangan hidup tetapi berbeda agama terpaksa mendorongnya untuk menjadi munafik dan tidak jujur. Banyak kasus dimana pasangan hidup pura-pura pindah agama, karena dilarang menikah berbeda agama. Tidak sedikit pula orang terpaksa pindah agama

\footnotetext{
50 Siti Musdah Mulia, "Kata Pengantar" dalam Mohammad Monib dan Ahmad Nurcholish, Kado Cinta bagi Pasangan Nikah Beda Agama, xiii.

${ }^{51}$ Adelbert Snijders, Manusia dan Kebenaran, Sebuah Filsafat Pengetahuan, Yokyakarta: Kanisius, $2016,129$.
} 
karena alasan pernikahan. Kalau bisa memilih keduanya secara bebas, mengapa harus memilih: agama atau menikah? Inilah salah satu contoh keburukan moral akibat dari larangan menikah bagi orang berbeda agama. Mengapa pula pernikahan harus menjadi alat proselitisme? Bukankah berpindah atau berganti agama seharusnya juga pilihan nurani?

Tentu saja seseorang tidak bisa dilarang pindah agama karena alasan menikah, asal sesuai dengan nuraninya, tidak dipaksa dan tidak terpaksa. Apabila itu dilakukannya karena dipaksa atau terpaksa, maka hal itu bertentangan dengan moral dan agama. Agama adalah hak paling asasi setiap orang maka setiap orang bebas memilih agama yang mau dianutnya sesuai dengan pilihan dan nuraninya. Termasuk tentu saja berpindah agama karena ingin menyesuaikan diri dengan agama pasangan hidupnya, tetapi sekali lagi bukan karena paksaan atau larangan.

Sampai saat ini Negara Kesatuan Republik Indonesia belum menjamin hak asasi warga Negara Indonesia dalam hal kebebasan menikah. Buktinya, pasangan yang menikah karena berbeda agama tidak dilayani oleh pemerintah dalam hal itu petugas Kantor Dinas Kependudukan dan Catatan Sipil (KDKCS). KDKCS hanya melayani mereka yang menikah dan yang menganut satu agama. Pelayanan seperti itu sangat diskriminatif dan itu berarti lembaga pernikahan telah direduksi menurut kepentingan agama dan mengabaikan kebebasan dan hak asasi manusia baik atas kebebasan menikah maupun atas kebebasan beragama. Mestinya secara konstitusi dan secara praktis, Negara menjamin kebebasan beragama dan kebebasan menikah tanpa pembatasan agama. Artinya pernikahan lintas iman harus dijamin oleh undang-undang dan dilayani baik oleh institusi Negara maupun oleh institusi agama. Pelayanan Negara dan institusi agama yang membedakan warganya atas dasar anutan agama, khusus mereka yang menikah dengan berbeda agamanya sudah terlalu lama diperlakukan diskriminatif. 
Ada beberapa implikasi etis/moral yang merugikan baik mereka yang menikah maupun merugikan Negara dan institusi agama itu sendiri. Pertama, banyak pasangan yang terpaksa harus meminta pelayanan dari Negara asing. Secara praktis hal seperti itu merugikan Negara baik dari segi ekonomi maupun politis dan moral. Mereka yang menikah keluar negeri mengeluarkan dana yang tidak sedikit. Kasus-kasus ini merugikan secara politis dan moral karena bangsa lain menganggap bangsa kita tidak mampu melayani warganya dan Negara Indonesia dicap sebagai Negara diskriminatif.

Kedua, pasangan yang tidak mampu ke luar negeri, dan ini lebih banyak, terpaksa menempuh pernikahan yang bertentangan dengan nuraninya, pindah agama tetapi tidak sungguhsungguh disertai keyakinan. Secara tidak langsung kita memaksa warga kita menjadi munafik. Pura-pura pindah agama pada saat dilangsungkan pernikahan, tetapi sesudah itu kembali lagi ke agamanya yang lama dan hal itu malah bisa menimbulkan kekisruhan dalam rumah tangga. Di sini institusi agama dirugikan, memiliki warga yang munafik.

Ketiga, mereka yang tidak bisa menempuh yang pertama dan kedua di atas, memilih untuk "kumpul kerbau" alias kawin tanpa menikah. Akibatnya, instituasi agama dan Negara dilecehkan dan lembaga pernikahan diturunkan wibawanya sebagai lembaga yang seharusnya dihormati oleh setiap warga Negara. Jangka panjang, Negara dan institusi agama dirugikan.

Banyak implikasi moral lain dari pelayanan diskriminatif terhadap warga Negara yang kawin campur dengan orang berbeda agama: status anak-anak mereka menjadi tidak jelas, kemungkinan terjadi ketidak-harmonisan rumah tangga, atau terjadinya kemunafikan. Secara umum, tindakan diskriminatif yang dilakukan baik institusi Negara maupun institusi agama terhadap mereka yang mempraktekkan nikah lintas iman, adalah tindakan tidak adil terhadap 
warga Negara. Oleh karena itu, pernikahan lintas iman harus dibuka seluas-luasnya sebagai konsekuensi logis dari sebuah Negara majemuk.

Ada dua alasan mengapa pernikahan lintas iman harus diberi peluang seluas-luasnya. Pertama, karena cinta harus menjadi pondasi utama setiap pernikahan dan jatuh cinta tidak boleh dibatasi atau dihalangi oleh perbedaan suku, agama, usia, pendidikan, status sosial atau perbedaan apapun. Kedua, pernikahan tidak boleh menjadi sarana proselit karena bertentangan dengan kebebasan seseorang untuk menganut agama sesuai nuraninya.

Tentu saja semua institusi agama berhak dan bertanggung jawab membina umatnya untuk menikah sesuai dengan keyakinannya, tetapi pembinaan itu tidak boleh menjadi hukum yang membatasi orang untuk terpaksa jatuh cinta dan terpaksa menikah dengan orang seagama atau seiman, kalau bertentangan dengan pilihan dan nuraninya. Negara dan institusi agama tetap berkewajiban melayani dan memfasilitasi hak dan kebebasan setiap warga Negara memilih oarng yang dicintai untuk menjadi pasangan hidupnya.

\section{Simpulan}

Indonesia sebagai Negara yang masyarakatnya majemuk tidak bisa mengabaikan realitas pernikahan lintas iman atau perkawinan campur bebrbeda agama, sebab itu dari sudut pandang agama, sudah seharusnya agama-agama di Indonesia lebih terbuka untuk mendalami dan mengajarkan melalui pendidikan pluralisme kultural. Para pemimpin agama harus mengajarkan sikap inklusif dan bukan sikap eksklusif-primordoalistik, sikap esoteric dan bukan sikap eksoterik terhadap warganya. Penghayatan terhadap kehidupan beragama justru akan semakin 
mendalam dan kuat melalui keterbukaan terhadap agama-agama yang berbeda. Konsekuensinya adalah lembaga agama menerima dan menyediakan sarana memfasilitasi pernikahan lintas iman.

Arah pendidikan agama kita memang harus diubah menjadi pendidikan multi agama atau pendidikan multi kultural. Atau sekurang-kurangnya memasukkan dengan sengaja dan terencana aspek pendidikan multi agama tersebut dalam pendidikan agama, baik di sekolah maupun di lembaga-lembaga agama sendiri. Pendidikan agama harus diarahkan untuk bisa saling menghargai, saling menghormati, termasuk menghargai dan menghormati pilihan setiap orang untuk menghayati agamanya dalam kehidupan bersama orang lain, termasuk emlalui lembaga perkawinan.

Kita mewarisi undang-undang kolonial yang memisahkan legalisasi pernikahan secara terkotak-kotak atas dasar segregasi agama. Memang dalam tradisi Eropa, legalisasi pernikahan merupakan hak prerogatif Negara menggantikan atau memperluas hak-hak kultural keluarga. Maka ketika agama-agama berperan memberkati pernikahan, maka terjadi dualisme dalam hal legalisasi pernikahan tersebut. Itu juga yang diterapkan pemerintah kolonial Belanda di Indonesia. Undang-undang perkawinan yang sekarang berlaku di Indonesia memperkuat posisi agama Islam dalam legalisasi pernikahan karena paham agama dan Negara berperan bersama, sedangkan posisi agama lain, khususnya Kristen, tetap masih seperti posisi pemerintahan Kolonial. Gereja hanya memberkati, pemerintah yang mensahkan dengan memberikan Akta Perkawinan. Mungkinkah undang-undang perkawinan yang baru (ke depan) melakukan penyeragaman, dengan menyerahkan sepenuhnya hak legalisasi pernikahan kepada Negara sehingga agama-agama hanya melakukan pemberkatan atau memberi restu secara rohani, sehingga Negara leluasa menikahkan orang-orang yang berbeda agama? Ini pekerjaan rumah 
bangsa bangsa Indonesia, dan umat beragama khususnya, supaya benang kusut pernikahan lintas iman bisa diurai atau diatasi.

\section{Daftar Pustaka}

Althaus, Paul, The Ethics of Martin Luther, Philadelphia: Fortress Press, 1973.

Anshor, Maria Ulfah \& Sinaga, Martin Lukito (ed.), Tafsir Ulang Perkawinan Lintas Agama:

Perspektif Perempuan dan Pluralisme, Jakarta: Kapal Perempuan 2004

Aritonang, Jan Sihar, Sejarah Perjumpaan Kristen dan Islam di Indonesia, Jakarta: BPK Gunung Mulia 2004.

Asmin, Status Perkawinan Antar Agama, ditinjau dari Undang-undang No.1/ 1974, Jakarta: Penerbit Dian Rakyat 1986.

Benedanto, Pax, (ed.), Kovenan Internasional Hal Sipil dan Politik, Jakarta: Lembaga Studi Pers \& Pembangunan, 2000.

Bertens, Kees, Etika, Jakarta: PT. Gramedia Pustaka Umum, 2004.

Coward, Harold, Pluralisme: Tantangan bagi Agama-agama, Yokyakarta, Kanisius, 1989.

Darmaputera, Eka, Etika Sederhana untuk Semua, Jakarta: BPK Gunung Mulia, 1987.

Ferm, Vergilius, (ed.), Encyclopedia of Morals, New York: Philosophical Morals, 1956.

Gautama, Sudargo, Segi-segi Hukum Peraturan Perkawinan Campuran (Staatblad 1898 Nomor 158), Bandung: Citra Aditya Bakti, 1996.

Go, Piet dan Suharto, Kawin Campur Beda Agama dan Beda Gereja, Malang: Penerbit Dioma, 1990.

Jonge, de Christiaan, Apa itu Calvinisme, Jakarta: BPK Gunung Mulia, 2011

Majelis Ulama Indonesia, Fatwa Munas VII Majelis Ulama Indonesia, Jakarta: MUI, 2005. 
Monib, Mohammad dan Nurcholish, Ahmad, Kado Cinta bagi Pasangan Nikah Beda Agama, Jakarta: Gramedia Pustaka Utama, Cet 2, 2009.

Prawiroamidjojo, R. Soetojo, Pluralisme dalam Perundang-undangan Perkawinan di Indonesia, Surabaya: Airlangga University Press, 1988.

Prodjodikoro, R. Wirjono, Hukum Antar Golongan di Indonesia, Cet.7, Jakarta: Sumur Bandung, 1981, 92.

Saleh, K. Wantjik, Himpunan Peraturan dan Undang-undang tentang Perkawinan, Jakarta: Ikhtiar Baru - Van Hoeve, 1974.

Sairin, Weinata \& Pattiasina, J.M., (peny.), Pelaksanaan Undang-undang Perkawinan dalam Perspektif Kristen, Jakarta: BPK Gunung Mulia 1996.

Singer, Peter (ed.), A Companion To Ethics, Massachusetts: Blackwell, 1997.

Snijders, Adelbert, Manusia dan Kebenaran, Sebuah Filsafat Pengetahuan, Yokyakarta: Kanisius, 2016.

Suseno, Franz magnis, Etika Dasar: Masalah-Masalah Pokok Filsafat Moral, Yogyakarta: Kanisius, 1987.

Verkuyl, J., Etika Kristen: Seksual, Cet. Ke 5, Jakarta: BPK Gunung Mulia, 1987.

Al. Andang I. Binawan, Perkawinan Campur Beda Agama dalam Pandangan Katolik, http://www.st-stefanus.or.id/artikel/artikel-bebas/pernikahan-campur-beda-agama-dalampandangan-katolik/, diakses 27 Mei 2017 https://en.wikipedia.org/wiki/Interfaith_marriage, diakses 29 Mei 2017. http://referensi.elsam.or.id/2014/09/kovenan-internasional-hak-ekonomi-sosial-dan-budaya/, diakses, 29 Mei 2017. 
http://www.bbc.com/indonesia/berita_indonesia/2014/12/141204_pernikahan_beda_agama, diakses 29 Mei 2017.

http://www.bbc.com/indonesia/berita_indonesia/2015/06/150618_indonesia_mk_nikah_bedaaga ma, diakses 29 Mei 2017.

https://www.kontras.org/baru/Kovenan\%20Ekosob.pdf, diakses 30 Mei 2017.

https://portal.mahkamahkonstitusi.go.id/eLaw/mg58ufsc89hrsg/UUD_1945_Perubahan.pdf, diakses, 30 Mei 2017.

http://wisnu.blog.uns.ac.id/2011/03/10/pengakuan-agama-khonghucu-di-indonesia/, diakses 15

Juni 2017

http://www.kompasiana.com/www.eman.com/pacaran-menurut-agama-katolik-kristen- danislam_54f35887745513792b6c71d1, diakses 27 Mei 2017

Wijaya, Leony, "Sahnya Perkawinan Beda Agama Ditinjau dari Undang - Undang Nomor 1 Tahun 1974 dan Agama -Agama di Indonesia”, Posted on MARCH 18, 2016 , https://anastasyaleony.wordpress.com/2016/03/18/sahnya-perkawinan-beda-agama-ditinjau-dariundang-undang-nomor-1-tahun-1974-dan-agama-agama-di-indonesia/, diakses 29 Mei 2017. 